\title{
FAKTOR PEMBENTUK MOTIVASI BELAJAR MAHASISWA DAN PERBEDAANNYA BERDASARKAN GENDER
}

\author{
Nengah Sukendri ${ }^{1}$ \\ ${ }^{1}$ STAHN Gde Pudja Mataram, nengah_sukendri@yahoo.co.id
}

\begin{abstract}
ABSTRAK
Penelitian ini bertujuan untuk menganalisis faktor pembentuk motivasi belajar mahasiswa dan perbedaannya berdasarkan gender di STAHN Gde Pudja Mataram. Jenis penelitian yang digunakan adalah kuantitatif komparatif dengan alat analisis berupa confirmatory factor untuk mencari faktor yang membentuk motivasi belajar mahasiswa dan uji $t$ tes independent untuk mengetahui perbedaan motivasi mahasiswa berdasarkan gender. Hasil Penelitian menunjukan bahwa faktor yang membentuk motivasi mahasiswa untuk kuliah di STAHN Gde Pudja Mataram adalah motivasi intrinsik dan ekstrinsik, dan secara keseluruhan telah terjadi kesetaraan gender baik laki-laki dan perempuan terutama ditinjau dari sudut pandang motivasi baik secara internal maupun eksternal.
\end{abstract}

Kata Kunci: Motivasi Intrinsik, Motivasi Ekstrinsik, Gender

\section{ABSTRACT}

This study aims to analyze form factor motivation to learn students and the difference by gender in STAHN Gde Pudja Mataram. Kind of research that is used is comparative with quantitative analysis tools of confirmatory factor to find factors that form the motivation to learn a student and t-independent tests to know the difference by gender. student motivationThe research results show that the factors that form the motivation of students for college in stahn gde pudja mataram is motivation intrinsic and extrinsic motivation, and as a whole there has been gender equality for men and women especially in terms point of view both intrinsic and extrinsic Motivation.

Key Word: Intrinsic Motivation, Extrinsic Motivation, Gender

\section{PENDAHULUAN}

Perguruan tinggi merupakan kelanjutan pendidikan menengah yang diselenggarakan untuk mempersiapkan peserta didik untuk menjadi anggota masyarakat yang memiliki kemampuan akademis dan professional yang dapat menerapkan, mengembangkan dan menciptakan ilmu pengetahuan, teknologi dan kesenian. Sekolah Tinggi Agama Hindu Negeri Gde Pudja Mataram merupakan salah satu perguruan tinggi di Indonesia khususnya merupakan perguruan tinggi Hindu di Kota Mataram.

Perguruan tinggi ini memiliki program sarjana terdiri dari empat jurusan yaitu Jurusan Dharma Acarya, Jurusan Dharma Duta, Jurusan Dharma Sastra dan Jurusan Brahma Widya yang masing-masing di bawahnya terdiri dari beberapa program studi yaitu Jurusan Dharma Acarya memiliki tiga program studi yang terdiri dari Program Studi Pendidikan Agama Hindu, Program Studi PG PAUD, dan Program Studi Pendidikan Seni dan Kebudayaan Agama Hindu; Jurusan Dharma Duta memiliki dua program studi yaitu Program Studi Penerangan Agama Hindu dan Program Studi Ekonomi Hindu; Jurusan Dharma Sastra memiliki Program Studi Hukum Hindu; Jurusan Brahma Widya memiliki Program Studi filsafat Agama Hindu. Program Magister STAHN Gde Pudja Mataram 
membuka program Magister Pendidikan Agama Hindu dan Magister Ilmu Komunikasi Hindu. Jumlah keseluruhan mahasiswa pada perguruan tinggi tersebut kurang lebih berjumlah 582 orang mahasiswa yang aktif yang terdiri dari 287 orang laki-laki dan 295 orang perempuan. Penerimaan mahasiswa baru dilakukan setiap tahunnya telah dilaksanakan sesuai dengan prosedur dan di bawah suatu tim kepanitiaan. Berikut ini merupakan informasi tentang penerimaan mahasiswa selama 4 tahun terakhir.

Tabel 1. Jumlah Mahasiswa STAHN Gde Pudja Mataram Periode 2015, 2016, 2017, 2018

\begin{tabular}{|l|l|c|c|c|c|}
\hline \multirow{2}{*}{ No. } & \multirow{2}{*}{ PROGRAM STUDI } & \multicolumn{4}{|c|}{ TAHUN (Jumlah Mahasiswa) } \\
\cline { 3 - 6 } & & $\mathbf{2 0 1 5}$ & $\mathbf{2 0 1 6}$ & $\mathbf{2 0 1 7}$ & $\mathbf{2 0 1 8}$ \\
\hline 1. & PENDIDIKAN AGAMA HINDU & 51 & 31 & 32 & 32 \\
\hline 2. & PENDIDIKAN PG PAUD & - & 7 & 14 & 9 \\
\hline 3. & PENDIDIKAN SENI & - & 8 & 5 & 18 \\
\hline 4. & FILSAFAT AGAMA HINDU & 10 & 5 & 6 & 9 \\
\hline 5. & PENERANGAN AGAMA HINDU & 14 & 17 & 21 & 21 \\
\hline 6. & HUKUM AGAMA HINDU & 11 & 12 & 23 & 35 \\
\hline 7. & EKONOMI HINDU & - & - & 12 & 76 \\
\hline
\end{tabular}

Sumber: Data Sekunder STAHN Gde Pudja Mataram, diolah

Pada Tabel 1 tersebut ada 3 program studi baru, yaitu Program Studi Ekonomi tahun 2017, Program Studi PG PAUD dan Program Studi Pendidikan Seni dan Kebudayaan Agama Hindu yang baru berdiri tahun 2016, sehingga data 2015 masih belum tersedia. Ada 2 program studi yang mengalami kecenderungan kenaikan jumlah mahasiswa selama 4 tahun terakhir yaitu Program Studi Hukum Agama Hindu dan Program Studi Penerangan Agama Hindu. Program Studi Pendidikan Agama Hindu mengalami penurunan yang cukup besar yaitu dari 51 menjadi 31 orang dari tahun 2015 ke 2016 dan tahun 2017 mengalami kenaikan sebanyak 1 orang dan jumlah mahasiswa tetap stabil di tahun 2018. Program Studi Filsafat Agama Hindu juga mengalami kecenderungan penurunan dari periode 2015 ke 2016 turun sebanyak 5 orang mahasiswa, namun 2017 mengalami kenaikan 1 orang dan di tahun 2018 juga ada kenaikan menjadi 9 orang. Program Studi Ekonomi Hindu, adanya kenaikan jumlah penerimaan mahasiswa baru yang sangat drastis dari 12 orang menjadi 76 orang di tahun 2018.

Bertambah maupun berkurangnya jumlah peminat atau calon mahasiswa sangat bergantung dari faktor pendorong baik dari dalam (faktor intrinsik) maupun dari luar (ekstrinsik). Penelitian dari Hakan dan Munire (2014) yang menggunakan faktor intrinsik dan ekstrinsik dalam academic motivation scale menunjukan adanya perbedaan motivasi antara mahasiswa dengan mahasiswi. Penelitian Sukendri (2017) yang bertujuan menganalisis perbedaan perilaku belanja antara mahasiswa dan mahasiswi di lingkungan STAHN Gde Pudja Mataram menunjukan bahwa ada perbedaan diantara mahasiswa dan mahasiswi dan perbedaan tersebut menunjukan bahwa mahasiswi memiliki perilaku belanja yang lebih besar dari pada mahasiswa. Penelitian lainnya dari Dumitru et al. (2014) menunjukan hasil bahwa tidak ada perbedaan (terjadi kesamaan) antara mahasiswa dengan mahasiswi ditinjau dari motivasinya. Berdasarkan riset gap atau perbedaaan hasil penelitian terdahulu dan fenomena terjadinya fluktuasi jumlah mahasiswa tersebut maka perlu adanya suatu kajian yang lebih mendalam mengenai faktor pembentuk motivasi belajar mahasiswa dan perbedaannya berdasarkan gender di STAHN Gde Pudja Mataram ditinjau dari motivasi yang terbentuk tersebut khususnya pada penerimaan mahasiswa baru tahun akademik 2017/2018. Perlu kiranya dilakukan 
penelitian yang bertujuan untuk menganalisis faktor pembentuk motivasi belajar mahasiswa dan perbedaannya berdasarkan gender.

\section{TINJAUAN LITERATUR}

Motif adalah apa yang menggerakkan seseorang untuk bertindak dengan cara tertentu atau sekurang-kurangnya mengembangkan suatu kecenderungan tertentu (Timotius: 2003). Motif dipahami sebagai ungkapan kebutuhan seseorang karenannya motif bersifat pribadi dan internal. Dipihak lain, insentif berasal dari luar. Insentif dijadikan sebagai bagian lingkungan kerja oleh pimpinan untuk mendorong karyawan melakukan tugasnya. Misalnya, pimpinan menawarkan bonus bagi wiraniaga sebagai insentif untuk mendorong tercapainya tingkat penjualan yang lebih tinggi dan juga memenuhi kebutuhan wiraniaga akan pengakuan dan status. Hamalik (2007) mengemukakan bahwa motivasi adalah perubahan energi dalam diri (pribadi) seseorang yang ditandai dengan timbulnya perasaan dan reaksi untuk mencapai tujuan.

Penelitian yang dilakukan Dumitru et al. (2014) menganalisis tentang perbedaan motivasi dari tujuan individu, tingkat aspritif berdasarkan gender. Analisis dilakukan pada 51 mahasiswa pada Universitas Bucharest di Rumania, yang terdiri dari 25 mahasiswa dan 26 mahasiswi di perguruan tinggi tersebut yang berusia diantara 20 tahun sampai dengan usia 24 tahun. Hasil menunjukan bahwa baik mahasiswa maupun mahasiswi memiliki kesamaan dalam motif individu, hal ini berarti motivasi diinduksi oleh tingkat konsentrasi dan perhatian dalam proses pembelajaran atau tidak ada hubungan antar gender dengan motif individu. Berdasarkan tingkat aspiratif menunjukan adanya perbedaan antara mahasiswa dan mahasiswi dimana mahasiswa lebih ditekankan pada konsentrasi sedangkan mahasiswi lebih pada perasaan.

Selanjutnya penelitian Hakan dan Munire (2014) yang membahas tentang perbedaan motivasi akademik berdasarkan gender, domain dan tingkatan pada mahasiswa dan mahasiswi pada tingkatan dan kelas yang berbeda. Pengamatan dilakukan pada 750 mahasiswa dan mahasiswi dari bagian (department) yang berbeda pula. Instrumen yang digunakan adalah berupa Academic Motivation Scale, dengan alat analisis uji-t. Hasil menunjukan bahwa ada perbedaan motivasi mahasiswa dan mahasiswi secara intinsik dan ekstirnsik berdasarkan gender, domain atau bidang keilmuan dan tingkatan (kelas) mahasiswa di Turki.

Kubaisy et al. (2015) menyatakan bahwa perempuan memiliki kemampuan fisik yang lebih rendah dari pada laki-laki. Berdasarkan hal tersebut dilakukan pengujian hubungan (korelasi) terkait 21 alasan motivasi kemampuan fisik dengan gender. Hasil menunjukan bahwa dari 21 faktor motivasi tersebut hanya 2 faktor yang memiliki hubungan terhadap gender yaitu faktor gaya atau pola seks dan energi yang digunakan untuk melakukan kegiatan sehari-hari. Hal yang menarik 19 faktor motivasi yang lainnya menunjukan tidak adanya hubungan antara faktor motivasi terhadap gender. Artinya secara umum tidak ada perbedaan antara laki-laki dan perempuan ditinjau dari motivasi kemampuan fisiknya.

Mahdavy (2013) melakukan penelitian yang membahas tentang hubungan gender terhadap siswa sekolah menengah atas (SMA) dalam pembelajaran Bahasa Inggris di Iran. Penelitian melibatkan 401 siswa SMA yang menggunakan Bahasa Inggris sebagai bahasa pengantar yang meliputi 96 siswa (murid laki-laki) dan 305 siswi (murid perempuan). Pengujian menggunakan 40 pertanyaan dengan instrumen kuesioner dan skala likert berskala 6. Alat analisis yang digunakan adalah uji Mann-Whitney dan menunjukan hasil bahwa faktor promosi berpengaruh bagi siswa (laki-laki) dalam keputusan pembelajaran Bahasa Inggris. Berbeda dengan faktor motivasi yang 
menunjukan tidak ada perbedaan antara siswa (laki-laki) dan siswi (perempuan) dalam hal motivasi pembelajaran Bahasa Inggris.

Ozturk dan Gurbuz (2013) menelaah pengaruh gender terhadap kecemasan berbahasa asing dan motivasi bagi para murid. Responden yang digunakan ada sebanyak 225 siswi dan 158 siswa yang tergabung dalam level intermediate. Teknik pengumpulan datanya menggabungkan antara kuesioner dengan wawancara dengan pendekatan gabungan (mixed method). Hasil analisis kuantitatif menggambarkan siswi lebih memiliki motivasi menggunakan bahasa asing yang lebih tinggi dibandingkan siswa, namun demikian hal cukup menarik juga adalah para siswi justru memiliki kecemasan yang lebih tinggi dalam menggunakan bahasa asing dibandingkan dengan siswa. Hasil analisis kualitatif menunjukan hal yang sama (parallelism) dengan hasil kuantitatif dimana siswi memiliki motivasi dan kecemasan dalam bahasa asing yang lebih tinggi dibandingkan dengan siswa.

Ada beberapa teori yang menjadi sebuah acuan dalam penelitian ini yaitu teori kepuasan yaitu teori ini menitikberatkan pada faktor-faktor apa saja yang dapat menguatkan, mengarahkan, mendukung dan menghentikan perilaku. Teori ini mencoba menjawab pertanyaan seputar kebutuhan apa yang dapat memuaskan dan mendorong semangat kerja seseorang. Yang dapat memotivasi semangat kerja seseorang adalah terpenuhinya kebutuhan serta kepuasaan terhadap materi maupun non materi yang diperolehnya dari bekerja. Menurut Gibson, (1996:190) Teori Kepuasan terdiri dari beberapa teori yaitu Teori Hirarki Kebutuhan oleh Maslow, Teori Kebutuhan Tiga Tingkat (ERG), Teori Kebutuhan Mc Clelland, dan Teori Dua faktor Herzberg.

Frederick Herzberg mengembangkan teori Model Dua Faktor dari motivasi yaitu faktor motivasional dan faktor higine atau pemeliharaan (Thoha, 1999:202). Faktor motivasional adalah faktor pendukung berprestasi yang bersifat intrinsik atau hakiki yang artinya bersumber dari dalam diri seseorang. Sedangkan faktor higine atau pemeliharaan yang bersifat ekstrinsik yang artinya bersumber dari luar diri seseorang dalam kehidupan kekaryaannya.

Anoraga dan Suyati (1995:75) dari hasil penelitian Herzberg menyimpulkan dua faktor yaitu :

1. Ekstrinsik yaitu suatu kondisi apabila tidak ada yang menyebabkan ketidakpuasan diantara karyawan. Kondisi ini disebut dengan hygiene factor, karena faktor-faktor tersebut. Dibutuhkan minimal untuk menjaga adanya ketidakpuasan. Faktor-faktor ini berkaitan dengan pekerjaan yang meliputi gaji, keamanan kerja, kondisi kerja, hubungan dengan rekan kerja, hubungan dengan penyelia dan kebijakan organisasi

2. Intrinsik yaitu suatu kondisi apabila dapat berfungsi sebagai motivator dapat menghasilkan prestasi kerja yang baik. Adapun faktor-faktor yang mampu memuaskan dan mendorong untuk bekerja dengan baik terdiri dari promosi, tanggung jawab, pengembangan, pengakuan, dan pekerjaan itu sendiri

Penelitian ini dimaksudkan untuk melihat apa saja sebagai pembentuk motivasi penerimaan mahasiswa baru yaitu motivasi intrinsik dan motivasi ekstrinsik mahasiswa baru yang kuliah dari jurusan-jurusan di STAHN Gde Pudja Mataram khususnya program studi S1 STAHN Gde Pudja Mataram pada tahun akademik 2017/2018. Ada empat jurusan yang dilihat yaitu jurusan Dharma Acarya, Dharma Duta, Dharma Sastra, dan Brahma Widya khususnya semua program studi yang ada di bawah jurusan. Berdasarkan analisis faktor yang digunakan, dapat diketahui faktor dominan yang membentuk motivasi penerimaan mahasiswa baru di STAHN Gde Pudja Mataram. Analisis faktor ini merupakan salah satu bentuk uji validitas dan reliabilitas indikator pembentuk variabel. 
Setelah itu dilakukan uji beda menggunakan uji t independen untuk mengetahui adanya perbedaan motivasi mahasiswa dan mahasiswi STAHN Gde Pudja Mataram.

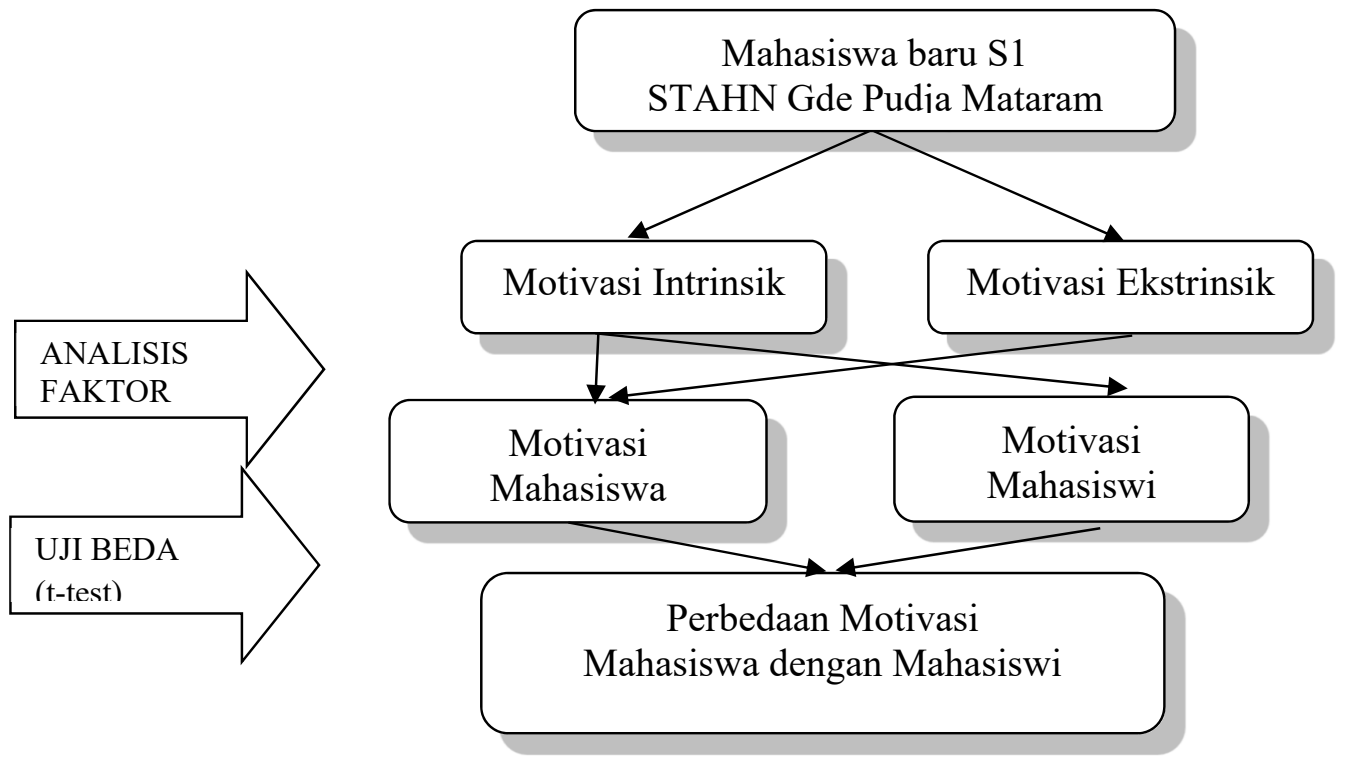

Gambar 1. Kerangka Konseptual

Berdasarkan pada Gambar 1 tersebut maka dapat disusun hipotesis penelitian sebagai berikut:

H1 : Diduga faktor-faktor yang membentuk motivasi mahasiswa untuk kuliah di STAHN Gde Pudja Mataram yaitu faktor eksternal dan internal.

H2 : Diduga ada perbedaan motivasi yang mempengaruhi penerimaan mahasiswa baru mahasiswa dan mahasiswi di STAHN Gde Pudja Mataram.

\section{Jenis Penelitian}

\section{METODE PENELITIAN}

Penelitian ini merupakan penelitian kuantitatif dengan jenis penelitian kuantitatif komparatif untuk menganalisis faktor pembentuk motivasi belajar mahasiswa dan perbedaannya berdasarkan gender di STAHN Gde Pudja Mataram.

\section{Lokasi Penelitian}

Penelitian ini dilakukan di STAHN Gde Pudja Mataram berdasarkan pertimbangan bahwa satu-satunya Sekolah Tinggi Agama Hindu Negeri di Mataram NTB. Relevansinya untuk mengetahui faktor pembentuk motivasi belajar mahasiswa dan perbedaannya berdasarkan gender di STAHN Gde Pudja Mataram.

\section{Jenis Data}

Jenis data yang digunakan dalam penelitian ini adalah data sekunder dan data primer. Data sekunder yang merupakan data yang diperoleh dari STAHN Gde Pudja Mataram, misalnya jumlah mahasiswa. Data primer merupakan data yang diperoleh langsung dilapangan tanpa melalui perantara, contohnya data pengumpulan kuesioner pada mahasiswa dan mahasiswi. 


\section{Teknik Pengumpulan Data dan Uji Intrumen}

Teknik pengumpulan data yang yang digunakan dalam penelitian ini adalah angket atau kuesioner dengan melakukan pembagian kuesioner untuk diisi oleh mahasiswa dan mahasiswi.

Penelitian kuantitatif dalam riset ini menggunakan data dari pengumpulan melalui kusioner, yang diawali dengan analisis konfirmasi faktor yaitu KMO dan BTS setelah itu baru dilakukan uji-t tes independen.

\section{Populasi dan Sampel Penelitian}

Populasi dalam penelitian ini adalah seluruh mahasiswa program S1 STAHN Gde Pudja Mataram. Pengambilan sampel dengan purposive sampling yaitu mahasiswa baru program S1 tahun akademik 2017/2018.

\section{Prosedur Analisis Data}

Analisis konfirmasi faktor tersebut dilakukan dan selanjutnya yaitu uji beda yang menggunakan analisis uji t (t-test) dua sampel Independen (independent t-test), yang digunakan dalam membandingkan faktor motivasi yang dominan antara mahasiswa dan mahasiswi. Uji t dua sampel ini tergolong uji perbandingan (komparatif). Menurut Riduwan (2011), uji kedua ini gunanya untuk menguji kemampuan generalisasi (signifikansi hasil penelitian) yang berupa perbandingan keadaan variabel dari dua ratarata sampel.

Dalam penelitian ini menggunakan SPSS (Statistical Package for the Social Science) 17.00. Kriteria pengujian uji t dua sampel dalam SPSS menurut Yamin (2009) adalah nilai $\rho$ value atau nilai signifikansi statistik t hitung $<$ dari 0,05 berarti ada perbedaan yang signifikan motivasi mahasiswa baru diitinjau dari sudut pandang gender.

\section{ANALISIS DATA}

\section{HASIL DAN PEMBAHASAN}

\section{Analisis Faktor}

Analisis konfirmasi faktor (confirmatory factor analysis) dalam penelitian ini berguna untuk melihat apa saja sebagai pembentuk motivasi penerimaan mahasiswa baru yaitu motivasi intrinsik dan motivasi ekstrinsik mahasiswa baru yang kuliah di STAHN Gde Pudja Mataram, yaitu mahasiswa baru angkatan tahun akademik 2017/2018. Dalam hal ini, semua program studi yang ada di bawah jurusan yaitu di bawah empat jurusan yang terdiri dari jurusan Dharma Acarya, Dharma Duta, Dharma Sastra, dan Brahma Widya.

Tabel 2 Asumsi KMO dan BTS Motivasi Intrinsik

\begin{tabular}{|llr|}
\hline Kaiser-Meyer-Olkin Measure of Sampling Adequacy. & .683 \\
Bartlett's Test of Sphericity & Approx. Chi-Square & 173.826 \\
& Df & 45 \\
& Sig. & .000 \\
\hline
\end{tabular}

Pada tabel 2 terlihat bahwa asumsi analisis faktor berupa KMO dan BTS terpenuhi yaitu ditunjukkan dengan KMO lebih besar dari 0,5 yaitu 0,683 dan nilai sig BTS lebih kecil dari 0,05 yaitu 0,000 yang artinya analisis faktor dapat dianalisis lebih lanjut dan dianggap tidak perlu melihat nilai Anti Image Correlation dari Motivasi Intrinsik. Setelah asumsi tersebut terpenuhi maka dapat dilanjutkan dengan melihat tabel total variance explain untuk mengetahui jumlah dan kemampuan menjelaskan faktor baru yang terbentuk. Faktor baru yang terbentuk adalah sebagai berikut. 
Tabel 3 Ringkasan Jumlah Faktor dan Determinasi Faktor Motivasi Intrinsik

\begin{tabular}{|c|r|r|r|r|r|r|r|r|r|}
\hline \multirow{2}{*}{$\begin{array}{c}\text { Compo } \\
\text { nent }\end{array}$} & \multicolumn{4}{|c|}{ Initial Eigenvalues } & \multicolumn{3}{c|}{$\begin{array}{c}\text { Extraction Sums of Squared } \\
\text { Loadings }\end{array}$} & \multicolumn{3}{c|}{$\begin{array}{c}\text { Rotation Sums of Squared } \\
\text { Loadings }\end{array}$} \\
\cline { 2 - 11 } & Total & $\begin{array}{c}\text { \% of } \\
\text { Variance }\end{array}$ & $\begin{array}{c}\text { Cumulat } \\
\text { ive } \%\end{array}$ & Total & $\begin{array}{c}\text { \% of } \\
\text { Variance }\end{array}$ & $\begin{array}{c}\text { Cumulat } \\
\text { ive } \%\end{array}$ & Total & $\begin{array}{c}\text { \% of } \\
\text { Variance }\end{array}$ & $\begin{array}{c}\text { Cumulative } \\
\%\end{array}$ \\
\hline 1 & 2.881 & 28.808 & 28.808 & 2.881 & 28.808 & 28.808 & 2.485 & 24.850 & 24.850 \\
\hline 2 & 1.763 & 17.629 & 46.437 & 1.763 & 17.629 & 46.437 & 1.958 & 19.578 & 44.429 \\
\hline 3 & 1.633 & 16.332 & 62.769 & 1.633 & 16.332 & 62.769 & 1.834 & 18.341 & 62.769 \\
\hline 4 & .971 & 9.711 & 72.480 & & & & & & \\
\hline 5 & .665 & 6.654 & 79.134 & & & & & & \\
\hline 6 & .510 & 5.099 & 84.234 & & & & & & \\
\hline 7 & .464 & 4.640 & 88.874 & & & & & & \\
\hline 8 & .428 & 4.283 & 93.157 & & & & & & \\
\hline 9 & .378 & 3.782 & 96.939 & & & & & & \\
\hline 10 & .306 & 3.061 & 100.000 & & & & & & \\
\hline
\end{tabular}

Tabel 3 menjelaskan ada 10 item pertanyaan yang membentuk motivasi intrinsik dan dari 10 item tersebut ada tiga faktor yang terbentuk pada motivasi intrinsik. Eigen value merupakan hasil perhitungan matrik bujur sangkar sehingga ketika hasil perhitungan eigen value yang lebih besar dari $1(>1)$ maka faktor yang baru terbentuk merupakan bagian sebuah variabel. Dalam hal ini, faktor 1 dengan eigen value 2,881 dan kemampuan menjelaskan faktor ini dalam membentuk faktor motivasi intrinsik adalah $28,808 \%$. Faktor 2 dengan eigen value 1,763 dan kemampuan menjelaskan faktor ini dalam membentuk faktor motivasi intrinsik adalah 17,629\%. Faktor 3 dengan eigen value 1,633 dan kemampuan menjelaskan faktor ini dalam membentuk faktor motivasi intrinsik adalah $16,332 \%$. Sedangkan, tujuh item lainnya tidak dapat dikatakan bagian atau pembentuk variabel motivasi intrinsik karena memiliki nilai eigen value yang lebih kecil dari $1(<1)$. Kemampuan secara kumulatif menjelaskan dari tiga faktor baru yang terbentuk dari motivasi intrinsik sebesar $62,769 \%$. Setelah diketahui ada 3 faktor yang terbentuk, maka dilanjutkan dengan item apa saja yang membentuk masing-masing faktor melalui rotated component matrix dengan metode varimax yaitu pemutaran data sejauh 90 derajat. Berikut ini adalah item yang terbentuk setelah data diputar.

Tabel 4, Faktor Pembentuk Motivasi Intrinsik

\begin{tabular}{|l|r|r|r|}
\hline \multirow{2}{*}{} & \multicolumn{3}{|c|}{ Component } \\
\cline { 2 - 4 } & $\mathbf{1}$ & $\mathbf{2}$ & $\mathbf{3}$ \\
\hline MOTIN1 & .705 & -.232 & .160 \\
\hline MOTIN2 & .771 & .064 & -.139 \\
\hline MOTIN3 & .748 & .148 & .238 \\
\hline MOTIN4 & .698 & .284 & .082 \\
\hline MOTIN5 & -.007 & .660 & -.215 \\
\hline MOTIN6 & .350 & .532 & .165 \\
\hline MOTIN7 & .354 & .718 & -.034 \\
\hline MOTIN8 & -.282 & .751 & .256 \\
\hline MOTIN9 & .103 & .026 & .893 \\
\hline MOTIN10 & .094 & -.005 & .888 \\
\hline & & & \\
\hline
\end{tabular}

Berdasarkan Tabel 4, bahwa ada tiga faktor yang terbentuk dari motivasi intrinsik. Item yang dominan membentuk faktor pertama adalah item motin 1 , motin 2 , motin 3 , 
dan motin 4 yaitu loading factor-nya di atas 0,5. Terlihat bahwa dari 4 item pembentuk motivasi intrinsik yang memiliki loading factor tertinggi ditunjukkan oleh item motin 2 yaitu sebesar 0,771 . Hal ini, menyebabkan faktor pertama yang terbentuk adalah faktor motivasi intrinsik dengan maju dalam karier.

Item yang dominan membentuk faktor kedua adalah item motin 5, motin 6, motin 7 , dan motin 8 yaitu loading factor-nya di atas 0,5 . Terlihat bahwa dari 4 item pembentuk motivasi intrinsik yang memiliki loading factor tertinggi ditunjukkan oleh item motin 8 yaitu sebesar 0,751 . Hal ini, menyebabkan faktor kedua yang terbentuk adalah faktor motivasi intrinsik dengan rasa suka tantangan. Item yang dominan membentuk faktor ketiga adalah item motin 9 , dan motin 10 yaitu loading factor-nya di atas 0,5 . Terlihat bahwa dari 2 item pembentuk motivasi intrinsik yang memiliki loading factor tertinggi ditunjukkan oleh nilai item motin 9 yaitu sebesar 0,893 . Hal ini, menyebabkan faktor ketiga yang terbentuk adalah faktor motivasi intrinsik dengan rasa tanggung jawab.

Selanjutnya untuk variabel kedua, yaitu motivasi ekstrinsik ditunjukkan dengan melihat hasil asumsi analisis faktor berupa KMO dan BTS, sebagai berikut.

Tabel 5, Asumsi KMO dan BTS Motivasi Ekstrinsik

\begin{tabular}{|c|c|c|}
\hline Kaiser-Meyer-Olkin Measu & f Sampling Adequacy. & \\
\hline Bartlett's Test of Sphericity & Approx. Chi-Square & 152.249 \\
\hline & Df & 28 \\
\hline & Sig. & .000 \\
\hline
\end{tabular}

Pada Tabel 5, asumsi analisis faktor berupa KMO dan BTS terpenuhi yaitu ditunjukkan dengan KMO lebih besar dari 0,5 yaitu 0,740 dan nilai sig BTS lebih kecil dari 0,05 yaitu 0,000 yang artinya analisis faktor dapat dianalisis lebih lanjut dan tidak perlu dilanjutkan dengan melihat nilai Anti Image Correlation dari Motivasi Ekstrinsik. Asumsi KMO dan BTS yang terpenuhi maka dilanjutkan dengan melihat tabel total variance explain untuk mengetahui jumlah dan kemampuan menjelaskan faktor baru yang terbentuk. Faktor baru yang terbentuk adalah sebagai berikut.

Tabel 6, Ringkasan Jumlah dan Determinasi Faktor Motivasi Ekstrinsik

\begin{tabular}{|c|r|r|r|r|r|r|r|r|r|}
\hline \multirow{2}{*}{$\begin{array}{c}\text { Compo } \\
\text { nent }\end{array}$} & \multicolumn{3}{|c|}{\begin{tabular}{c} 
Initial Eigenvalues \\
\cline { 2 - 10 }
\end{tabular}} & \multicolumn{1}{c|}{$\begin{array}{c}\text { Extraction Sums of Squared } \\
\text { Loadings }\end{array}$} & \multicolumn{3}{c|}{$\begin{array}{c}\text { Rotation Sums of Squared } \\
\text { Loadings }\end{array}$} \\
\hline 1 & 3.116 & 38.953 & 38.953 & 3.116 & 38.953 & 38.953 & 2.462 & 30.774 & 30.774 \\
\hline 2 & 1.381 & 17.258 & 56.210 & 1.381 & 17.258 & 56.210 & 2.035 & 25.436 & 56.210 \\
\hline 3 & .969 & 12.114 & 68.324 & & & & & & \\
\hline 4 & .766 & 9.570 & 77.894 & & & & & & \\
\hline 5 & .745 & 9.316 & 87.210 & & & & & & \\
\hline 6 & .411 & 5.133 & 92.343 & & & & & & \\
\hline 7 & .333 & 4.164 & 96.507 & & & & & & \\
\hline 8 & .279 & 3.493 & 100.000 & & & & & & \\
\hline
\end{tabular}

Tabel 6 tersebut menjelaskan bahwa ada dua faktor yang terbentuk pada motivasi ekstrinsik. Eigen value merupakan hasil perhitungan matrik bujur sangkar sehingga ketika hasil perhitungan eigen value yang lebih besar dari $1(>1)$ maka faktor yang baru terbentuk merupakan bagian sebuah variabel. Dalam hal ini, faktor 1 dengan eigen value 3,116 dan kemampuan menjelaskan faktor ini dalam membentuk faktor motivasi ekstrinsik adalah 38,953 \%. Faktor 2 dengan eigen value 1,381 dan kemampuan 
menjelaskan faktor ini dalam membentuk faktor motivasi ekstrinsik adalah 17,258 \%. Sedangkan, delapan faktor lainnya tidak dapat dikatakan bagian atau pembentuk variabel motivasi ekstrinsik karena memiliki nilai eigen value yang lebih kecil dari $1(<1)$. Kemampuan secara kumulatif menjelaskan dari tiga faktor baru yang terbentuk dari motivasi ekstrinsik sebesar 56,210 \%. Setelah mengetahui jumlah faktor yang terbentuk dari 8 item tersebut, maka selanjutnya dilakukan identifikasi item mana saja yang membentuk masing-masing faktor. Ternyata setelah data diputar, maka item yang terbentuk digambarkan pada Tabel 7.

Tabel 7, Faktor Pembentuk Motivasi Ekstri
\begin{tabular}{|l|r|r|}
\hline & \multicolumn{2}{|c|}{ Component } \\
\cline { 2 - 3 } & \multicolumn{1}{|c|}{1} & \multicolumn{1}{|c|}{2} \\
\hline MOTEK1 & .499 & .316 \\
MOTEK2 & .285 & .142 \\
MOTEK3 & .878 & -.099 \\
MOTEK4 & .746 & .325 \\
MOTEK5 & .842 & .175 \\
MOTEK6 & .260 & .540 \\
MOTEK7 & .107 & .850 \\
MOTEK8 & .125 & .869 \\
\hline
\end{tabular}

Tabel 7 menunjukan bahwa ada dua faktor yang terbentuk dari motivasi ekstrinsik. Item yang dominan membentuk faktor pertama adalah item motek 3 , motek 4 , dan motek 5 yaitu loading factor-nya di atas 0,5. Terlihat bahwa dari 3 item pembentuk motivasi ekstrinsik yang memiliki loading factor tertinggi ditunjukkan oleh nilai item motek 3 yaitu sebesar 0,878 . Hal ini, menyebabkan faktor pertama yang terbentuk adalah faktor motivasi ekstrinsik dengan kondisi yang bersih.

Item yang dominan membentuk faktor kedua adalah item motek 7 dan motek 8 yaitu loading factor-nya di atas 0,5. Terlihat bahwa dari 2 item pembentuk motivasi ekstrinsik yang memiliki loading factor tertinggi ditunjukkan oleh nilai item motek 8 yaitu sebesar 0,869 . Hal ini, menyebabkan faktor kedua yang terbentuk adalah faktor motivasi ekstrinsik dengan hubungan sosial yaitu lembaga dengan masyarakat dan dunia kerja cukup baik.

\section{Uji t-Independent}

Analisis uji beda yang menggunakan analisis uji t ( $t$-test) dua sampel Independen (independent $t$-test), dilakukan untuk membandingkan faktor motivasi antara mahasiswa dan mahasiswi STAHN Gde Pudja Mataram tahun akademik 2017/2018. Setelah analisis konfirmasi faktor (confirmatory factor analysis) tersebut di atas, maka dilakukan analisis uji beda yang menggunakan analisis uji $\mathrm{t}$ ( $t$-test) dua sampel Independen, dalam penelitian ini dilakukan uji beda dengan membandingkan faktor motivasi antara mahasiswa dan mahasiswi STAHN Gde Pudja Mataram tahun akademik 2017/2018. Oleh karena itu, diperoleh hasil uji $\mathrm{t}$ tes independen untuk variabel motivasi intrinsik dengan motivasi ekstrinsik.

Hasil data uji t tes independen yang diperoleh motivasi intrinsik dengan faktor maju, suka dan tantangan serta tanggung jawab lebih jelasnya dapat dilihat pada Tabel 8 berikut. 
Tabel 8, Hasil Uji t terhadap tiga faktor pembentuk motivasi intrinsik

\begin{tabular}{|c|c|c|c|c|c|c|c|c|c|c|}
\hline & \multicolumn{2}{|c|}{$\begin{array}{c}\text { Levene's Test } \\
\text { for Equality } \\
\text { of Variances }\end{array}$} & \multicolumn{7}{|c|}{ t-test for Equality of Means } \\
\hline & & \multirow[t]{2}{*}{$\mathbf{F}$} & \multirow[t]{2}{*}{ Sig. } & \multirow[t]{2}{*}{$t$} & \multirow[t]{2}{*}{ Df } & \multirow{2}{*}{$\begin{array}{l}\text { Sig. (2- } \\
\text { tailed) }\end{array}$} & \multirow{2}{*}{$\begin{array}{c}\text { Mean } \\
\text { Difference }\end{array}$} & \multirow{2}{*}{$\begin{array}{l}\text { Std. Error } \\
\text { Difference }\end{array}$} & \multicolumn{2}{|c|}{$\begin{array}{l}95 \% \text { Confidence Interval } \\
\text { of the Difference }\end{array}$} \\
\hline & & & & & & & & & Lower & Upper \\
\hline \multirow[t]{2}{*}{$\begin{array}{l}\text { FAKTOR } \\
\text { MAJU }\end{array}$} & $\begin{array}{l}\text { Equal variances } \\
\text { assumed }\end{array}$ & 1.806 & .184 & -.258 & 66 & .797 & -.06329297 & .24519921 & -.55284899 & .42626306 \\
\hline & $\begin{array}{l}\text { Equal variances } \\
\text { not assumed }\end{array}$ & & & -.249 & 50.532 & .804 & -.06329297 & .25386880 & -.57307045 & .44648452 \\
\hline \multirow{2}{*}{$\begin{array}{l}\text { FAKTOR } \\
\text { SUKA, } \\
\text { TANTAN } \\
\text { GAN }\end{array}$} & $\begin{array}{l}\text { Equal variances } \\
\text { assumed }\end{array}$ & 1.485 & .227 & 1.807 & 66 & .075 & .43269232 & .23947159 & -.04542814 & .91081278 \\
\hline & $\begin{array}{l}\text { Equal variances } \\
\text { not assumed }\end{array}$ & & & 1.757 & 53.596 & .085 & .43269232 & .24623175 & -.06105791 & .92644254 \\
\hline \multirow[t]{2}{*}{$\begin{array}{l}\text { FAKTOR } \\
\text { TGJWB }\end{array}$} & $\begin{array}{l}\text { Equal variances } \\
\text { assumed }\end{array}$ & .072 & .789 & -1.613 & 66 & .112 & -.38812392 & .24062611 & -.86854944 & .09230161 \\
\hline & $\begin{array}{l}\text { Equal variances } \\
\text { not assumed }\end{array}$ & & & -1.589 & 59.046 & .117 & -.38812392 & .24423809 & -.87683519 & .10058736 \\
\hline
\end{tabular}

Tabel 8 menjelaskan bahwa faktor maju, suka tantangan, dan tanggung jawab antara jawaban mahasiswa dan mahasiswi memiliki tingkat homogenitas yang sama. Hal ini terbukti dari semua faktor ketika diuji dengan levene test memiliki tingkat signifikansi yang lebih besar dari 0,05 yang berarti keseluruhan data faktor yang diuji pada mahasiswa dan mahasiswi untuk motivasi intrinsik memiliki kesamaan varian. Adanya kesamaan varian antara mahasiswa dan mahasiswi tersebut maka dilakukan analisis dengan menggunakan asumsi kesamaan varian (equal variances assumed).

Adapun hasil data yang diperoleh dari perbedaan motivasi intrinsik antara mahasiswa dan mahasiswi STAHN Gde Pudja Mataram menunjukkan nilai signifikansi 2 arah (sig. 2 tailed) lebih besar dari 0,05, yaitu secara berturut-turut faktor maju, suka tantangan, dan tanggung jawab memiliki signifikansi 0,$797 ; 0,075 ; 0,112$ artinya tidak memiliki perbedaan atau sama antara mahasiswa dan mahasiswi dalam membentuk motivasi intrinsik dari ketiga faktor yang diuji.

Setelah dilakukan uji beda terhadap faktor-faktor intrinsik, selanjutnya juga dilakukan analisis terhadap hasil uji beda menggunakan dua faktor yang terbentuk dari variabel ekstrinsik yaitu faktor kondisi dan faktor hubungan sosial. Hasil data uji t tes independen yang diperoleh motivasi ekstrinsik dengan faktor kondisi dan hubungan sosial lebih jelasnya dapat dilihat pada Tabel 9 berikut ini.

Tabel 9, Hasil Uji t terhadap dua faktor pembentuk motivasi ekstrinsik

\begin{tabular}{|c|c|c|c|c|c|c|c|c|c|c|}
\hline & \multicolumn{2}{|c|}{$\begin{array}{l}\text { Levene's Test } \\
\text { for Equality } \\
\text { of Variances }\end{array}$} & \multicolumn{7}{|c|}{ t-test for Equality of Means } \\
\hline & & \multirow[t]{2}{*}{$\mathbf{F}$} & \multirow[t]{2}{*}{ Sig. } & \multirow[t]{2}{*}{$\mathbf{t}$} & \multirow[t]{2}{*}{ Df } & \multirow[t]{2}{*}{$\begin{array}{l}\text { Sig. (2- } \\
\text { tailed) }\end{array}$} & \multirow[t]{2}{*}{$\begin{array}{c}\text { Mean } \\
\text { Difference }\end{array}$} & \multirow[t]{2}{*}{$\begin{array}{l}\text { Std. Error } \\
\text { Difference }\end{array}$} & \multicolumn{2}{|c|}{$\begin{array}{l}\text { 95\% Confidence } \\
\text { Interval of the } \\
\text { Difference }\end{array}$} \\
\hline & & & & & & & & & Lower & Upper \\
\hline \multirow[t]{2}{*}{$\begin{array}{l}\text { FAKTORK } \\
\text { ONDISI }\end{array}$} & \begin{tabular}{|l} 
Equal \\
variances \\
assumed
\end{tabular} & .311 & .579 & .014 & 66 & .989 & .00349868 & .24532257 & -.48630364 & .49330100 \\
\hline & \begin{tabular}{|l|} 
Equal \\
variances \\
not \\
assumed
\end{tabular} & & & .014 & 60.003 & .989 & .00349868 & .24838385 & -.49334246 & .50033982 \\
\hline $\begin{array}{l}\text { FAKTORH } \\
\text { UBSOS }\end{array}$ & $\begin{array}{l}\text { Equal } \\
\text { variances } \\
\text { assumed }\end{array}$ & .172 & .680 & .765 & 66 & .447 & .18691393 & .24424169 & -.30073035 & .67455820 \\
\hline
\end{tabular}




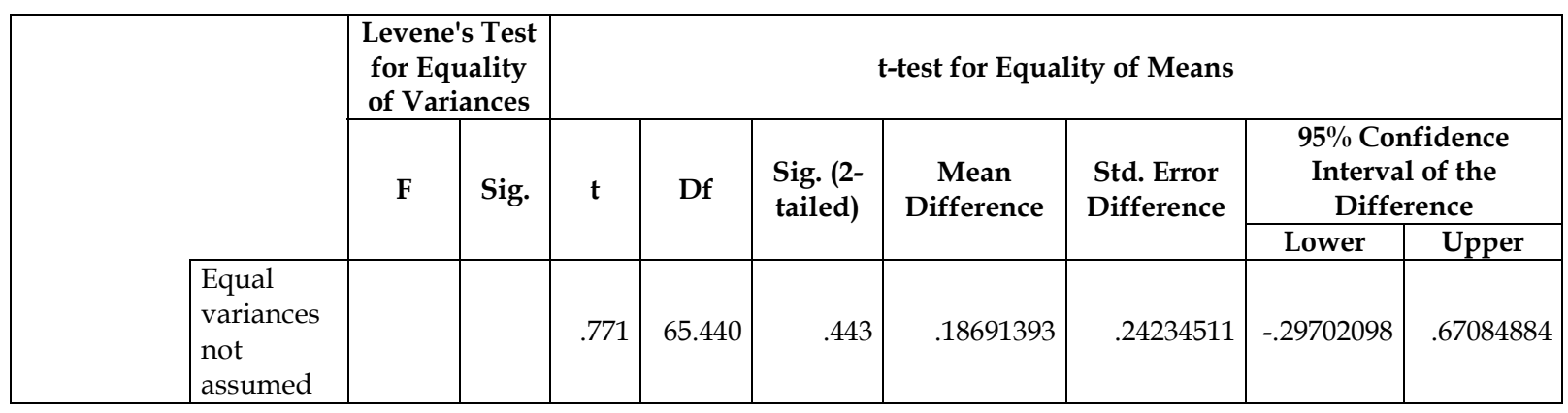

Tabel 9 menjelaskan bahwa faktor kondisi dan hubungan sosial antara jawaban mahasiswa dan mahasiswi memiliki tingkat homogenitas yang sama. Hal ini terbukti dari semua faktor ketika diuji dengan levene test memiliki tingkat signifikansi yang lebih besar dari 0,05 yang berarti keseluran data faktor yang diuji pada mahasiswa dan mahasiswi untuk motivasi ekstrinsik memiliki kesamaan varian. Adanya kesamaan varian antara mahasiswa dan mahasiswi tersebut maka dilakukan analisis dengan menggunakan asumsi kesamaan varian (equal variances assumed).

Adapun hasil data yang diperoleh dari perbedaan motivasi ekstrinsik antara mahasiswa dan mahasiswi STAHN Gde Pudja Mataram menunjukkan nilai signifikansi 2 arah (sig. 2 tailed) lebih besar dari 0,05, yaitu secara berturut-turut faktor kondisi dan hubungan sosial memiliki signifikansi 0,$989 ; 0,447$ artinya tidak memiliki perbedaan atau sama antara mahasiswa dan mahasiswi dalam membentuk motivasi ekstrinsik.

\section{PEMBAHASAN}

Adapun motivasi intrinsik diperoleh faktor yang terbentuk yaitu faktor maju, suka tantangan, dan tanggung jawab. Artinya, terkait motivasi intrinsik dengan faktor maju yaitu mahasiswa STAHN Gde Pudja Mataram secara individu sangat termotivasi untuk kuliah di STAHN Gde Pudja Mataram sesuai dengan kondisi yang ada untuk kuliah di sekolah ini, selain itu mahasiswa STAHN Gde Pudja Mataram termotivasi untuk kuliah karena memiliki kepedulian terhadap pendidikan dimana pembelajaran di STAHN Gde Pudja Mataram dapat dirasakan dengan sangat menyenangkan dan bermanfaat bagi masa depan.

Terkait motivasi intrinsik dengan faktor suka tantangan yaitu mahasiswa STAHN Gde Pudja Mataram secara individu termotivasi untuk kuliah di STAHN Gde Pudja Mataram karena merasa tertantang walaupun harus dengan wajib membayar SPP, selain itu banyak mahasiswa kuliah yang berorentasi untuk karier kerja kedepanya atau memikirkan peluang karier dalam bekerja (dalam hal ini maksudnya banyak yang mengikuti perkuliahan walaupun sudah bekerja sehingga mengikuti perkuliahan karena merasa tertantang dan untuk mendapatkan pengetahuan serta wawasan yang lebih mendalam sesuai dengan program studi yang dipilih). Mahasiswa STAHN Gde Pudja Mataram secara keseluruhan termotivasi untuk kuliah di lembaga ini walaupun sekolah lain menerima mereka, karena kuliah di STAHN Gde Pudja dianggap menyenangkan.

Terkait motivasi intrinsik pada faktor tanggung jawab yaitu mahasiswa STAHN Gde Pudja Mataram secara individu termotivasi untuk kuliah di sekolah ini karena merupakan salah satu tanggung jawab mereka sehingga berkewajiban untuk menyelesaikan kuliah sebagai bentuk tanggung jawab. Tanggung jawab disini merupakan beban yang dirasakan oleh mahasiswa sebagai mahasiswa sekaligus sebagai sebagai 
seorang anak bagi orang tuanya dirumah, jika mereka tidak dapat melakasanakan status mereka dengan baik.

Motivasi ekstrinsik diperoleh faktor yang terbentuk yaitu faktor kondisi dan hubungan sosial. Artinya, terkait motivasi ekstrinsik dengan faktor kondisi yaitu mahasiswa STAHN Gde Pudja Mataram sangat termotivasi untuk kuliah di STAHN Gde Pudja Mataram karena gedung kuliahnya bersih, tertata rapi, memiliki tempat parkir dengan ketersediaan Satpam sehingga mahasiswa memiliki ketenangan dan kenyamanan untuk mengikuti perkuliahan. Sedangkan, terkait motivasi ekstrinsik dengan faktor hubungan sosial yaitu mahasiswa STAHN Gde Pudja Mataram sangat termotivasi untuk kuliah di STAHN Gde Pudja Mataram karena hubungan lembaga dengan masyarakat dan dunia kerja cukup baik, dimana STAHN Gde Pudja Mataram merupakan Sekolah Tinggi Hindu yang benuansa Agama Hindu Negeri yang ada di Nusa Tenggara Barat. Selain itu, hubungan antara dosen, mahasiswa dan tenaga administrasi bahkan dengan alumni berlangsung cukup baik, sehingga perkuliahan dan proses pembelajaran di STAHN Gde Pudja Mataram dapat berjalan dengan baik dan lancar serta sesuai harapan masyarakat.

Berdasarkan hasil analisis uji t tes independen, diperoleh hasil data uji beda pada motivasi intrinsik dan motivasi ekstrinsik. Motivasi intrinsik antara mahasiswa dan mahasiswi STAHN Gde Pudja Mataram menunjukkan bahwa tidak ada perbedaan antara mahasiswa dan mahasiswi STAHN Gde Pudja Mataram. Artinya, bahwa motivasi intrinsik terkait faktor maju, suka tantangan dan tanggung jawab mahasiswa di STAHN Gde Pudja Mataram baik laki-laki maupun perempuan tidak ada perbedaan atau sama.

Hal tersebut berarti ketiga faktor yang membentuk variabel intrinsik diantara mahasiswa dan mahasiswi yaitu faktor maju, suka tantangan, dan tanggung jawab tidak berbeda antara mahasiswa dan mahasiswi. Keduanya menganggap ketiga hal tersebut sebagai hal yang penting secara internal dalam memotivasi untuk mengikuti kuliah dan memiliki daya tarik untuk kuliah di lembaga tersebut. Mahasiswa dan mahasiswi berasumsi bahwa kuliah di kampus bernuansa Hindu Negeri di Kota Mataram akan dapat memiliki masa depan yang lebih baik. Hal tersebut selaras dengan faktor kedua yaitu adanya tantangan bagi mereka yang kuliah sambil bekerja juga menyenangkan, mereka yakin bahwa dengan melanjutkan studi di perguruan tinggi akan meningkatkan wawasan sekaligus karier mereka di dunia kerja. Menurut teori dua faktor Herzberg, hal tersebut sesuai dengan indikator promosi dan pengembangan. Demikian pula dengan faktor tangung jawab, baik laki-laki maupun perempuan sama-sama memiliki rasa tanggung jawab sebagai mahasiswa di kampus dan rumah. Rasa tanggung jawab terkait erat dengan pengakuan status mereka terutama di masyarakat sebagai mahasiswa yang sesuai dengan teori dua faktor dari Herzberg.

Motivasi ekstrinsik antara mahasiswa dan mahasiswi juga menunjukkan hal yang sama, bahwa tidak ada perbedaan persepsi di antara mahasiswa dan mahasiswi terkait motivasi. Artinya, bahwa motivasi ekstrinsik yang terdiri dari faktor kondisi dan hubungan sosial mahasiswa ditinjau dari isu gender tidak ada perbedaan, atau sama. Lakilaki maupun perempuan memiliki kesetaraan (kesetaraan gender) dilihat dari perspektif motivasi eksternal. Faktor kondisi merupakan keadaan kampus terkait dengan fasilitas yang tersedia sampai dengan kenyamanan, keamanan dan kebersihan lingkungan kampus merupakan hal penting dalam menarik minat calon mahasiswa untuk kuliah di kampus tersebut. Suatu kewajaran jika hal ini sangat diperhatikan calon mahasiswa, karena hal tersebut sangat erat kaitannya dengan kelancaran proses belajar dan mengajar dalam proses pembelajaran. Selaras dengan kondisi, faktor kedua pembentuk motivasi eksternal adalah hubungan sosial. Faktor kedua ini juga merupakan alasan utama lainnya bagi masyarakat untuk menjadi mahasiswa karena relasional kampus dengan stakeholder 
selama ini telah berlangsung dengan cukup baik. Para pemangku kepentingan seperti tenaga pendidik (dosen), mahasiswa, tenaga kependidikan (pegawai administrasi), Sulinggih, PHDI, Alumni, Pemerintah dan masyarakat luas memiliki harapan bahwa STAHN Gde Pudja Mataram mampu menjadi mercusuar bagi masyarakat Mataram khususnya dan NTB pada umumnya dalam membangun sumber daya manusia dan karakter dalam industri 4.0 saat ini. Baik laki-laki maupun perempuan menyoroti hubungan yang dibangun kampus dengan lingkungan dan stakeholder merupakan daya tarik tersendiri untuk kuliah di kampus ini.

\section{KESIMPULAN DAN IMPLIKASI}

Berdasarkan hasil dan pembahasan hasil yang telah dilakukan sebelumnya maka dapat disusun kesimpulan sebagai berikut:

Faktor-faktor yang membentuk motivasi mahasiswa untuk kuliah di STAHN Gde Pudja Mataram adalah motivasi intrinsik dan motivasi ekstrinsik. Faktor motivasi intrinsik yang membentuk motivasi mahasiswa kuliah di STAHN Gde Pudja Mataram adalah maju dalam karier, rasa suka tantangan dan tanggung jawab. Sedangkan faktor motivasi ekstrinsik yang membentuk motivasi mahasiswa kuliah di STAHN Gde Pudja Mataram adalah kondisi dan hubungan sosial. Terkait tentang perbedaan faktor motivasi yang membentuk motivasi di antara mahasiswa laki-laki dan perempuan di STAHN Gde Pudja Mataram menjelaskan bahwa motivasi intrinsik yaitu maju dalam karier, rasa suka tantangan dan tanggung jawab tidak berbeda nyata secara statistik antara mahasiswa lakilaki dan perempuan di STAHN Gde Pudja Mataram. Sama halnya dengan motivasi ekstrinsik, menjelaskan bahwa tidak ada perbedaan secara nyata dalam hal kondisi dan hubungan sosial antara mahasiswa laki-laki dan perempuan. Secara keseluruhan dapat disimpulkan saat ini telah terjadi kesetaraan gender baik laki-laki dan perempuan terutama ditinjau dari sudut pandang motivasi baik secara internal maupun secara eksternal.

\section{SARAN}

Berdasarkan hasil, pembahasan dan kesimpulan yang telah disampaikan, maka disarankan hal-hal sebagai berikut:

1 Bagi peneliti lain yang tertarik dengan masalah ini dapat melakukan penelitian yang lebih mendalam mengenai motivasi mahasiswa di STAHN Gde Pudja Mataram ataupun di lokasi penelitian yang berbeda.

2 Bagi tenaga pendidik dan orang tua harus bisa lebih meningkatkan motivasi belajar kepada mahasiswa terutama yang bisa membentuk adalah motivasi ekstrinsik berupa pengakuan atau memberikan reward bila berprestasi.

3 Bagi tenaga pendidik dapat meningkatkan kualitas pembelajaran agar sesuai dengan harapan masyarakat.

4 Bagi tenaga kependidikan dapat meningkatkan pelayanan sehingga dapat menunjang dan memperlancar proses pembelajaran yang dapat meningkatkan motivasi belajar mahasiswa. 


\section{REFRENSI}

Anoraga, P., dan Suyati, S. 1995. Perilaku Keorganisasian. Jakarta: PT. Dunia Pustaka Jaya.

Dumitru, D., Chraif, M. dan Anitei, M. 2014. Motivation and Cognitive Tasks. Correlative Study Between Genders, Procedia - Social and Behavioral Sciences, Vol. 127, $828-833$.

Gibson, I. \& Donelly. 1996. Organisasi, Perilaku, Struktur dan Proses, Edisi Kedelapan. Jakarta: Bina Aksara.

Hamalik, Oemar 2007. Proses Belajar Mengajar. Jakarta: PT. Bumi Aksara.

Hakan, K., dan Munire, E. 2014. Academic Motivation: Gender, Domain and Grade Differences, Procedia - Social and Behavioral Sciences, Vol. 143, 708 - 715.

Kubaisy, W.A., Mohamad, M., Ismail, Z. dan Abdullah, N.N. 2015. Gender Differences: Motivations for Performing Physical Exercise Among Adults in Shah Alam, Procedia - Social and Behavioral Sciences, Vol. 202, 522 - 530.

Mahdavy, B. 2013. Gender and Motivational Orientations of English Language Learners: The Case of High School Students In Iran, Procedia - Social and Behavioral Sciences, Vol. 70, $1056-1061$.

Ozturk, G. dan Gurbuz, N. 2013. The impact of gender on foreign language speaking anxiety and motivation, Procedia - Social and Behavioral Sciences, Vol.70, 654 665.

Riduwan. 2011. Dasar-Dasar Statistika. Bandung: Alfabeta.

Sukendri, Nengah. 2017. Perbedaan Perilaku Belanja Antara Mahasiswa dan Mahasiswi di STAHN Gde Pudja Mataram. Distribusi, Vol. 5, No. 1,73-84.

Thoha, m. 1999. perilaku Organisasi, Konsep Dasar dan Aplikasinya. Jakarta: Raja Grafindo Persada.

Timotius. 2003. Hubungan Motivasi Kerja Dengan Kinerja Guru. www.geocities.com.

Yamin, S \& Heri K. 2009. SPSS Complete. Teknik Analisis Statistik Terlengkap dengan Software SPSS. Jakarta: Salemba Infotek. 